Note

\title{
ULTRASONOGRAPHY AS A PREDICTING TOOL FOR CARCASS TRAITS OF YOUNG BULLS
}

\author{
Liliane Suguisawa $^{1}$; Wilson Roberto Soares Mattos ${ }^{1 *}$; Henrique Nunes de Oliveira ${ }^{2}$; Antônio \\ Carlos Silveira ${ }^{2}$; Mário de Beni Arrigoni²; Cláudio Maluf Haddad ${ }^{1}$; Luis Artur Loyola Chardulo; \\ Cyntia Ludovico Martins ${ }^{3}$ \\ ${ }^{1}$ USP/ESALQ - Depto. de Zootecnia, C.P. 9 - 13418-900 - Piracicaba, SP - Brasil. \\ ${ }^{2} U N E S P / F M V Z$ - Depto. de Melhoramento e Nutrição Animal, C.P. 560 - 18618-000 -Botucatu, SP - Brasil. \\ ${ }^{3}$ UNESP/IB - Depto. de Química e Bioquímica, C.P. 510 - 18618-000 - Botucatu, SP - Brasil. \\ *Corresponding author <w.mattos@esalq.usp.br>
}

\begin{abstract}
Considerable resources have been allocated to support research in the development of noninvasive and non-destructive techniques for carcass composition and quality evaluation. Ultrasonography is a reliable and relatively low-cost technique that can be used. In the present study, real-time ultrasonography was used to predict ribeye area (REA) and subcutaneous fat thickness (FT) in live animals as compared to carcass measurements. Animals used were 115 yearling bull calves (initial body weight, $329 \mathrm{~kg}$ ), kept under feedlot conditions, of four genetic groups (30, 1/2 Angus x Nellore; 30, 1/2 Canchim x Nellore; 30, 1/2 Simmental $\mathrm{x}$ Nellore, and 25 Nellore), and two finishing frame sizes (small and large). Four ultrasonographic measurements were taken every 28 days until slaughter. Predictive precision of ultrasonographic measurements increased as animals approached slaughter, reaching maximum values at the last measurement $\left(R^{2}=0.68\right.$ and 0.82 for REA and FT, respectively). FT carcass measurements was influenced by genetic group and live measurements $(P<0.05)$. Frame size did not influence REA and FT, probably due to small, but distinctive differences among genetic groups.
\end{abstract}

Key words: beef cattle, ribeye area, fat thickness, growth, cross breeds

\section{ULTRA-SONOGRAFIA PARA PREDIÇÃO DAS CARACTERÍSTICAS DA CARCAÇA DE BOVINOS JOVENS EM CONFINAMENTO}

\begin{abstract}
RESUMO: O desenvolvimento de técnicas não invasivas e não destrutivas para a avaliação da composição e qualidade de carcaça em animais tem mobilizado consideráveis recursos em pesquisa. A ultra-sonografia aparece neste contexto como uma técnica viável, confiável e de custo aceitável para esta função. No presente trabalho foi avaliada a técnica de ultra-sonografia em tempo real como ferramenta para predição da área de olho-de-lombo (AOL) e espessura da camada de gordura subcutânea (ECG) a partir de imagens tomadas em animais vivos, quando comparadas com as medições na carcaça. Foram utilizados 115 bovinos jovens (30, 1/2 Angus x Nellore; 30, 1/2 Canchim x Nellore; 30, 1/2 Simental x Nellore, e 25 Nellores), com peso inicial médio de $329 \mathrm{~kg}$ e de dois tamanhos à maturidade (pequeno e grande), no sistema de produção do novilho superprecoce. As medidas de ultra-sonografia foram realizadas a cada 28 dias totalizando quatro medições até o final do confinamento. A precisão da predição aumentou em função da proximidade da data do abate, sendo máxima na quarta medida $\left(R^{2}=0,68\right.$ para AOL e 0,82 para ECG). Houve efeito de grupo genético e de medida ultra-sonográfica para ECG. O tamanho corporal não teve efeito sobre nenhuma das características estudadas.

Palavras-chave: bovinos de corte, área de olho-de-lombo, gordura subcutânea, crescimento, grupos genéticos
\end{abstract}

\section{INTRODUCTION}

Genotype and environmental variables (especially nutrition) affect growth and development in beef cattle. According to Hammond (1971), growth can be defined as the accumulation of mass, while development refers to changes in shape and functioning of individuals. Adequate nutrition and management strategies are important to allow efficient beef production and maximize carcass yield.
High quality carcass should have minimal backfat cover to assure its preservation and maintenance of its desirable traits to consumers. Body composition and carcass yield are important parameters to be considered in ration formulation in feedlot cattle to support high daily gains and slaughtering at 12 to 15 months old (Silveira et al., 1999).

The development of non-invasive and non-destructive techniques to evaluate carcass composition and 
quality has mobilized considerable research resources. Ultrasonography is emphasized within this context as a viable (Frost et al., 1997), reliable and acceptable costeffective technique (Houghton \& Turlington, 1992). Ultrasound live measurements can be utilized to estimate muscle growth, predict carcass composition (Bailey et al., 1986; Faulkner et al., 1990; Perry \& Fox, 1997; Renand \& Fisher, 1997) and yield of commercial meat cuts (Waldner et al., 1992; Hassen et al., 1999b), as well as to estimate animal body condition score and nutritional status (Busboom et al., 2000).

Live measurements are taken from the Longissimus dorsi muscle section area (REA), and from the backfat layer thickness (FT) in the same muscle, based on images made between the $12^{\text {th }}$ and $13^{\text {th }}$ ribs. Values obtained by experienced technicians in live animals have shown high correlations with carcass measurements (Hassen et al., 1998; Moser et al., 1998; Hassen et al., 1999a).

Even though ultrasonography is a widespread technique within the scientific community, many research reports still show inconsistent accuracy results, especially REA values (Brethour, 1992; Robinson et al., 1992; Busboom et al., 2000; Perry \& Fox, 1997; May et al., 2000). Others consider this technique efficient only for REA estimation (Bullock et al., 1991; Bergen et al., 1997; Hassen et al., 1999a; Prado et al., 2001).

Differences between live animal and carcass measurements can be attributed to several factors: method used for hide removal, which can remove quite a variable amount of backfat from the carcass; carcass hanging procedure, which will affect its conformation; rigor mortis development; inadequate REA measurement; incorrect separation of the section between the $12^{\text {th }}$ and $13^{\text {th }}$ ribs, and carcass wrapping (Brethour, 1992; Perkins et al., 1992a; Robinson et al., 1992; Bergen et al., 1996).

Other factors such as ultrasound manufacturer and model, measurement magnitude (FT thickness and REA size) and technician's skill, may influence measurements' precision, as reported by several authors (Perkins et al., 1992b; Charagu et al., 2000; Greiner, 2001). Positioning of the probe both in live animal and in carcass is also a source of variation. The present work evaluated real-time ultrasound technique as a potential tool for predicting carcass traits in feeder young bulls.

\section{MATERIAL AND METHODS}

The trial was carried out in Botucatu, SP, Brazil (22 $53^{\prime}$ '09'S and $48^{\circ} 26^{\prime} 42^{\prime \prime} \mathrm{W}$ ), from October 19, 2000 to March 13, 2001. One hundred and fifteen bull calves (initial body weight, $329 \mathrm{~kg}$ ), crosses from Nellore damns sired by Angus, Canchim, Simmental and Nellore bulls, were randomly alloted by breed and size to 23 feedlot pens. Thirty animals were analyzed per cross at slaugh- tering, 15 small- and 15 large-framed (10 for Nellore crosses). Fnishing frame size (FS) criteria used was according to methodology described by Dhuyvetter (1995), using the equation:

FS $=-11.45+(0.04878 \times$ hip height $)-(0.0289 \times$ age $)$ $+(0.00001947 \times \text { age })^{2}+(0.0000334 \times$ hip height $) \times($ age $)$

Due to their different origins, animals started the feeding period at different dates: Simmental crosses in10/ 19/2000; Angus and Canchim crosses in 10/25/2000; and Nellore animals in 10/27/2000. Animals were treated for endo- and ectoparasites (Ivermectin) and fed isoenergetic $\left(\mathrm{NE}_{\mathrm{g}}=1.14 \mathrm{Mcal} / \mathrm{kg}\right)$ and isoproteic $(\mathrm{CP}=16 \%)$ diets formulated according to NRC (1996) recommendations, level II, for an estimated gain of $1.35 \mathrm{~kg} /$ day. Roughage:concentrate ratio was $21: 79$, dry matter basis (Table 1).

Animals were fed two equal daily meals, at 8:00 am and 15:00 pm. Feed consumption per pen was adjusted weekly. Animals were submitted to a 15-day adaptation period in which the roughage:concentrate ratio started at 40:60 and was gradually increased to the final ratio. Animals had free access to automatic water troughs.

Weights (12-h fasting) and ultrasound measurements were taken every 28 days, according to methodology described by Herring et al. (1994). The scanning site, between the $12^{\text {th }}$ and $13^{\text {th }}$ ribs of the animals' left side, was cleanned and vegetable oil was used to obtain adequate acoustic contact. The probe was placed perpendicularly to the rib-eye length (Longissimus dorsi muscle) between the $12^{\text {th }}$ and $13^{\text {th }}$ ribs, to measure REA; FT was measured at the muscle's distal third. The ultrasound equipment used was a Pie Medical 200 VET Scanner, 3.5 $\mathrm{MHz}, 18-\mathrm{cm}$ transducer probe, and a contour-fitting standoff.

After 111, 119 and 139 days of feeding period for Simmental, Angus and Canchim crosses and Nellore animals, respectively, cattle were slaughtered with minimum weight of $480 \mathrm{~kg}$ and FT of $3 \mathrm{~mm}$, for all genetic groups. After slaughtering carcasses were identified, weighed and chilled at $-5^{\circ} \mathrm{C}$.

Table 1 - Diet composition for animals in the feedlot.

\begin{tabular}{lc}
\hline Diet composition & $\%$ of dry matter \\
\hline Chopped grass hay & 21.0 \\
Cracked corn & 61.5 \\
Soybean meal & 10.0 \\
Nucleus* & 7.5 \\
\hline
\end{tabular}

*Nucleus composition: urea $6.25 \%$, dry yeast $68.75 \%$, mineral mix** $25 \%$ and Rumensinâ 3 ppm

**Composition of the mineral mix per kilogram of product: $75 \mathrm{~g} \mathrm{P}$; 126 g Ca; 160 g Na; 240 g Cl; 20 g S; 15 mg Mg; 4,000 mg Zn; $1,800 \mathrm{mg} \mathrm{Cu} ; 1,500 \mathrm{mg} \mathrm{Fe} ; 1,400 \mathrm{mg} \mathrm{Mn} ; 150 \mathrm{mg} \mathrm{Co} ; 120 \mathrm{mg} \mathrm{I}$; $15 \mathrm{mg} \mathrm{Se} ; 750 \mathrm{mg}$ F (max); palatability enhancer $50 \mathrm{mg}$. 
After two weeks of storage, 65 samples were collected from the section between the $12^{\text {th }}$ and $13^{\text {th }}$ ribs of 18 Angus, 17 Canchim and 12 Simmental crosses and 18 Nellore animals, to determine carcass REA and FT. REA was obtained with the use of a quadrant grade ruler (Luchiari Filho, 2000), while FT was measured with a caliper rule.

A split-plot experimental design was used to analyze ultrasound measurements, with plots arranged in a $4 \times 2$ factorial scheme (four genetic groups $\times$ two finishing frame sizes) and subplots consisting of replicated measurements for each animal within breed and frame size. Analysis of other traits followed a completely randomized design. Degrees of freedom were partitioned for traits showing interaction effects; the Student-NewmanKeuls (SNK) test was used for means comparisons. Preliminary statistical analyses showed a small effect of finishing frame size on measured traits and therefore removed from the final model.

Regression analyses were performed to test ultrasound accuracy in predicting carcass traits. The live animal variables REA and FT were used as independent variables in a stepwise multiple regression procedure to determine the equation to adequately estimate carcass composition. All analyses were performed through the PROC REG procedure of the SAS statistical analysis system (SAS, 1987). The determination coefficients $\left(R^{2}\right)$ of models that included, or not, the predictive variables were compared in those analyses, to evaluate the predictive value of ultrasound measurements, disregarding genetic group and maturity effects. All analyses were performed by the PROC REG procedure of the SAS statistical analysis system (SAS, 1987).

\section{RESULTS AND DISCUSSION}

Genetic group and feeding period affected $(P<0.05)$ animal live weight and ultrasound measurements; there were also interaction effects $(P<0.05)$ between genetic group and feeding period (Table 2). Animal age had no effect on carcass traits probably due to animal uniformity among genetic groups. Initial body weight was highest, intermediate and lowest for Simmental crosses, Nellore and Angus and Canchim crosses, respectively, $(P<0.05)$.

As expected, Simmental crosses were the heaviest animals $(P<0.05)$, during the whole feeding period. Canchim and Angus crosses and Nellore had the same final body weight even though they were different at the beginning of the feeding period $(P<0.05)$.

Ultrasound measurements of REA and FT were affected $(P<0.05)$ both by genetic group and interaction genetic group $\mathrm{x}$ period, probably as a result of different patterns in muscular growth and backfat accretion among genetic groups. REA in Nellore and Angus crosses showed lower values $(P<0.05)$ at the beginning of the feeding period, whereas they equaled REA values of the other two genetic groups by the end of the study. This was an unexpected trend, for Simmental crosses showest the highest body weight in the last two measurements even though Angus crosses and Nellore showed the same body weight.

Last REA live measurements (REA4) were the same among genetic groups (Table 2). Carcass REA and FT measurements showed a behavior similar to the findings of Bergen et al. (1996; 1997). Simmental crosses showed the highest REA, while Angus and Canchim

Table 2 - Live weight and ultrasound measurements for genetic groups.

\begin{tabular}{|c|c|c|c|c|c|c|}
\hline \multirow[b]{2}{*}{ Variable } & \multirow[b]{2}{*}{$\mathrm{n}$} & \multicolumn{5}{|c|}{ Genetic group } \\
\hline & & Angus cross & Canchim cross & Simmental cross & Nellore & $\mathrm{CV}$ \\
\hline Weight 1 (kg) & 116 & $305.9^{c} \pm 3.48$ & $305.9^{c} \pm 3.70$ & $368.9^{a} \pm 4.49$ & $339.5^{\mathrm{b}} \pm 3.53$ & 10.25 \\
\hline REA $1\left(\mathrm{~cm}^{2}\right)$ & 116 & $48.9^{\mathrm{b}} \pm 0.80$ & $53.5^{\mathrm{a}} \pm 0.89$ & $54.4^{\mathrm{a}} \pm 1.03$ & $50.3^{\mathrm{b}} \pm 1.14$ & 10.80 \\
\hline FT $1(\mathrm{~mm})$ & 116 & $1.6 b^{c} \pm 0.10$ & $1.4^{\mathrm{c}} \pm 0.09$ & $1.9^{b} \pm 0.13$ & $2.3^{a} \pm 0.15$ & 41.09 \\
\hline Weight 2 (kg) & 116 & $350.3^{c} \pm 3.42$ & $342.7^{c} \pm 4.15$ & $408.0^{\mathrm{a}} \pm 5.02$ & $374.7^{\mathrm{b}} \pm 4.39$ & 9.38 \\
\hline REA $2(\mathrm{~cm} 2)$ & 115 & $54.0^{c} \pm 0.85$ & $57.1^{b} \pm 0.90$ & $59.8^{a} \pm 0.86$ & $53.4^{c} \pm 0.87$ & 9.44 \\
\hline FT $2(\mathrm{~mm})$ & 115 & $2.2^{\mathrm{a}} \pm 0.15$ & $1.6^{b} \pm 0.08$ & $2.1^{\mathrm{a}} \pm 0.15$ & $2.4^{\mathrm{a}} \pm 0.15$ & 37.12 \\
\hline Weight 3 (kg) & 115 & $401.0^{\mathrm{b}} \pm 3.94$ & $392.0^{\mathrm{b}} \pm 5.03$ & $451.7^{\mathrm{a}} \pm 5.67$ & $407.8^{b} \pm 4.78$ & 8.50 \\
\hline REA $3\left(\mathrm{~cm}^{2}\right)$ & 115 & $66.8^{\mathrm{a}} \pm 1.07$ & $67.1^{\mathrm{a}} \pm 1.16$ & $68.4^{\mathrm{a}} \pm 1.05$ & $66.0^{\mathrm{a}} \pm 1.39$ & 9.23 \\
\hline FT $3(\mathrm{~mm})$ & 116 & $4.7^{\mathrm{a}} \pm 0.30$ & $3.2^{b} \pm 0.25$ & $2.9^{b} \pm 0.17$ & $3.4^{b} \pm 0.23$ & 41.62 \\
\hline Weight 4 (kg) & 115 & $443.6^{\mathrm{b}} \pm 4.53$ & $430.3^{b} \pm 5.98$ & $477.4^{\mathrm{a}} \pm 6.05$ & $434.6^{\mathrm{b}} \pm 5.65$ & 7.85 \\
\hline REA $4\left(\mathrm{~cm}^{2}\right)$ & 111 & $72.8^{a} \pm 1.12$ & $71.6^{a} \pm 1.48$ & $73.6^{a} \pm 1.13$ & $70.1^{\mathrm{a}} \pm 1.40$ & 9.42 \\
\hline FT 4 (mm) & 113 & $6.2^{\mathrm{a}} \pm 0.45$ & $3.8^{b} \pm 0.25$ & $3.7 \pm 0.24^{\mathrm{b}}$ & $4.0^{b} \pm 0.35$ & 45.61 \\
\hline REA Carcass $\left(\mathrm{cm}^{2}\right)$ & 60 & $77.8^{b} \pm 1.68$ & $79.6^{b} \pm 1.62$ & $86.0^{\mathrm{a}} \pm 2.51$ & $70.1^{c} \pm 1.90$ & 12.47 \\
\hline FT Carcass (mm) & 60 & $7.0^{\mathrm{a}} \pm 0.51$ & $5.6^{b} \pm 0.41$ & $3.3^{c} \pm 0.27$ & $2.3^{c} \pm 0.19$ & 52.72 \\
\hline
\end{tabular}

${ }_{\mathrm{a}, \mathrm{b}, \mathrm{c}}$ Means followed by common letters on the same row are not different $(P>0.05)$. 
crosses had intermediate and Nellore the lowest values. Angus crosses showed the highest, Canchim crosses intermediate, and Simmental crosses and Nellore the lowest carcass FT values, $(P<0.05)$.

The fact the last two ultrasound REA measurements (REA3 and REA4) were the same among genetic provides additional support to some authors's findings in that, there is a low REA predicting accuracy in heavier animals, that is, the higher the REA values, the lower the accuracy (Hougthon \& Turlington, 1992; Perkins et al., 1992a; Smith et al., 1992; Herring et al., 1994). Despite the fact live measurements shows high accuracy for REA in Nellore animals, as reported previously by Oltjen et al. (1989), this technique underestimated REA values for the remaining genetic groups in this study.

Initial FT measurements were low for every genetic group, reflecting the grazing regime the animals were kept before the trial started. This supports the fact FT is a difficult trait to be measured under pasture conditions, as pointed out by Aiken et al. (2001) and Prado et al. (2001). In this study Nellore animals had the highest FT value $(P<0.05)$ at the first ultrasound measurement among all groups, and had the same values as for Canchim and Simmental crosses by the end of the feeding period, when Angus crosses showed the highest FT values $(P<0.05)$. This was an expected result for Angus crosses (early maturity animals) start fat deposition earlier than other genetic groups, as already shown in other studies (Bergen et al., 1996; 1997). The FT values at the last period (FT4) as compared to the carcass values for Canchim crosses were very inconsistent as a great discrepancy of results from the final ultrasound data (FT4) with regard to carcass measures referred to the Canchim half-breeds, which had greater carcass FT values than Nellore animals and Simmental half-breeds.

Prediction equations based on live measurements are shown in Tables 3 and 4 . The $\left(R^{2}\right)$ values in Table 3 were relatively high (0.66 to 0.83$)$, when breeds and regression effect were included in the FT prediction model. The $\left(R^{2}\right)$ for the model including breed effect only was 0.66 and considerably lower $(0.48)$ when the last FT measurement only was included in the model.

The regression equation obtained with the inclusion of the last ultrasound measurement (FT4), including the genetic group effect, showed a $R^{2}$ equal to 0.82 . Thus, $47 \%$ of carcass composition variation, not caused by the genetic group, was due to FT. The $R^{2}$ of 0.82 in the equation including FT4 and genetic group is higher than the values obtained by Bullock et al. (1991) (0.62) and Silva et al. (2001) (0.76), and equal to that reported by Perry \& Fox (1997).

The prediction equations including genetic group and FT showed an increase in accuracy as animals approached slaughtering, which is in agreement with results reported by Bergen et al. (1997). Although some reports show a decrease in accuracy as FT values increase, accuracy increases as cattle approach slaughtering due to a small weight gain variation among animals. Further, the highest carcass FT value found in this study was $7.04 \mathrm{~mm}$ for Angus crosses, whereas accuracy starts to be impaired when FT values are higher than $10 \mathrm{~mm}$ (Faulkner et al., 1990; Perkins et al., 1992a; Waldner et al., 1992; Bergen et al., 1996).

The $R^{2}$ values for the regression equations to estimate REA when breeds and regression effect were included in the model were lower (0.54 to 0.77) than the values for FT prediction equations (Table 4). The model including genetic group effect only had a considerable low $R^{2}(0.36)$ and, contrasting with FT's equation $R^{2}$ value, $R^{2}$ was higher (0.49) when the last REA measurement only was included in the model.

The regression equation obtained with the inclusion of the last live measurement (REA4), including genetic group effect, showed a $R^{2}$ equal to 0.68 , indicat-

Table 3 - Regression equation components for carcass FT prediction from live measurements.

\begin{tabular}{|c|c|c|c|c|c|c|c|c|c|c|}
\hline \multicolumn{5}{|c|}{ Intercept } & \multicolumn{4}{|c|}{ Regression Coefficient } & \multirow{2}{*}{$\mathrm{R}^{2}$} & \multirow{2}{*}{$\begin{array}{l}\text { Standard } \\
\text { deviation }\end{array}$} \\
\hline General & $1 / 2$ Angus & 1/2 Canchim & $1 / 2$ Simmental & Nellore & FT 1 & FT 2 & FT 3 & FT 4 & & \\
\hline \multicolumn{11}{|c|}{ General model not including breed effect } \\
\hline 1.26 & & & & & & & & 0.76 & 0.48 & 1.70 \\
\hline \multicolumn{11}{|c|}{ Breed effect* } \\
\hline & 7.04 & 5.59 & 2.34 & 3.30 & & & & & 0.66 & 1.41 \\
\hline \multicolumn{11}{|c|}{ Models including breed and regression effect } \\
\hline & 6.16 & 4.79 & 2.23 & 1.15 & 0.71 & & & & 0.68 & 1.37 \\
\hline & 6.21 & 4.99 & 2.59 & 1.46 & & 0.36 & & & 0.66 & 1.40 \\
\hline & 3.94 & 3.69 & 1.37 & 0.39 & & & 0.61 & & 0.75 & 1.22 \\
\hline & 2.89 & 3.48 & 0.95 & 0.15 & & & & 0.61 & 0.82 & 1.03 \\
\hline & 3.06 & 3.55 & 0.81 & 0.05 & 0.42 & -0.16 & -0.30 & 0.76 & 0.83 & 1.03 \\
\hline
\end{tabular}

"The intercept represents the measurement mean for the breed. 
Table 4 - Regression equation components for carcass REA prediction from live measurements.

\begin{tabular}{|c|c|c|c|c|c|c|c|c|c|c|}
\hline \multicolumn{5}{|c|}{ Intercept } & \multicolumn{4}{|c|}{ Regression Coefficient } & \multirow{2}{*}{$\mathrm{R}^{2}$} & \multirow{2}{*}{$\begin{array}{l}\text { Standard } \\
\text { deviation }\end{array}$} \\
\hline General & $1 / 2$ Angus & $1 / 2$ Canchim & $1 / 2$ Simmental & Nellore & REA 1 & REA 2 & REA 3 & REA 4 & & \\
\hline \multicolumn{11}{|c|}{ General model not including breed effect } \\
\hline 16.6 & & & & & & & & 0.84 & 0.49 & 6.45 \\
\hline \multicolumn{11}{|c|}{ Breed effect* } \\
\hline & 7.04 & 5.59 & 2.34 & 3.30 & & & & & 0.36 & 7.33 \\
\hline \multicolumn{11}{|c|}{ Models including breed and regression effect } \\
\hline & 42.32 & 41.06 & 46.45 & 34.03 & 0.55 & & & & 0.54 & 6.35 \\
\hline & 31.84 & 31.97 & 36.56 & 26.73 & & 0.83 & & & 0.58 & 6.05 \\
\hline & 41.84 & 43.57 & 48.20 & 34.91 & & & 0.54 & & 0.51 & 6.50 \\
\hline & 26.14 & 29.86 & 33.75 & 22.49 & & & & 0.69 & 0.68 & 5.23 \\
\hline & 1.49 & 3.38 & 6.39 & -2.10 & 0.14 & 0.35 & 0.26 & 0.43 & 0.77 & 4.58 \\
\hline
\end{tabular}

*The intercept represents the measurement mean for the breed.

ing that $50 \%$ of carcass composition variation, not caused by genetic group, was due to REA4. This value is lower than the one reported by Perry \& Fox (1997) $\left(R^{2}=0.79\right)$, and higher than the value of Silva et al. (2001) $\left(R^{2}=0.55\right)$. This relatively low value for $R^{2}$ (0.68) could be due to variations regarding the probe positioning in the animal, problems while cleaning the scanning site and changes in carcass shape resulting from rigor mortis. The prediction equations including genetic group and REA showed an increase in accuracy as animals approached slaughtering, the same trend obtained for carcass FT prediction regressions. The $R^{2}$ values were for both FT (0.48) and REA (0.49) prediction equations where the last live measurement only was included in the model. Therefore, correlations between live, prior to slaugther, and carcass measurements are around $70 \%$.

When genetic group effect is included in the models in addition to last live measurements, substantial increases in precision were obtained for both traits, mainly for FT ( $R^{2}$ increased from 0.48 to 0.82 ). For both traits, live measurements explained approximately the same proportion of residual variation when the model included both variables and when genetic group was the only variable (47 and $48 \%$ for FT; 50 and $49 \%$ for REA, respectively).

The model which included all four live measurements showed neglible (for FT) and small (for RAE) improvements in prediction power as compared to models which included the last live measurement only.

\section{CONCLUSION}

In this study real-time linear array ultrasound live measurements was a precise method for FT carcass prediction but not for REA in young bulls finished under feedlot conditions.

\section{REFERENCES}

AIKEN, G.; ROUQUETTE Jr., F.M.; BROWN Jr., A.H. Sources of error for ultrasonic measurements of steer composition traits in grazing studies. In: INTERNATIONAL GRASSLAND CONGRESS, 19., São Pedro, 2001. Proceedings. Piracicaba: FEALQ, 2001. p.1043-1044.

BAILEY, C.; JENSEN, J.; BECH ANDERSEN, B. Ultrasonics scanning and body measurements for predicting composition and muscle distribution in young Holstein x Friesian bulls. Journal of Animal Science, v.63, p.1337-1346, 1986.

BERGEN, R.D.; McKINNON, J.J.; CHRISTENSEN, D.A.; KOHLE, N.; BELANGER, A. Prediction of lean yield in yearling bulls using realtime ultra-sound. Canadian Journal of Animal Science, v.76, p.305$311,1996$.

BERGEN, R.D.; McKINNON, J.J.; CHRISTENSEN, D.A.; KOHLE, N.; BELANGER, A. Use of the real-time ultrasound to evaluate live animal carcass traits in young performance-tested beef bulls. Journal of Animal Science, v.73, p.2300-2307, 1997.

BRETHOUR, J.R. The repeatability and accuracy of ultrasound in measuring back fat of cattle. Journal of Animal Science, v.70, p.1039-1044, 1992.

BULLOCK, K.D.; BERTRAND, J.K.; BENYSHEK, L.L.; WILLIANS, S.E.; LUST, D.G. Comparison of real-time ultrasound and other live measures to carcass measures as predictors of beef cow energy stores. Journal of Animal Science, v.69, p.3908-3916, 1991.

BUSBOOM, J.A.; BRETHOUR, J.R.; ELIAS-CALLES, A.; GASKINS, C.T; DUCKETT, S.K. Using ultrasound for prediction feeding and marketing of cattle. http://www.ansci.wsu.edu/wagyu/wagsymp/ articles97/busboom.htm, (10/Feb/2000).

CHARAGU, P.K.; CREWS Jr., D.H.; KEMP, R.A.; MWANSA, P.B. Machine effects of ultrasonic prediction of backfat and ribeye area in beef bulls, steers and heifers. Canadian Journal of Animal Science, v.80, p.19-24, 2000.

DHUYVETTER, J. Beef cattle frame scores. Fargo: NDSU, 1995. 2p.

FAULKNER, D.B.; PARRET, D.F.; McKEITH, F.K.; BERGER, L.L. Prediction of fat cover and carcass composition from live and carcass measurements. Journal of Animal Science, v.68, p.604-610, 1990.

FROST, A.R.; SCHOFIELD, C.P.; BEAULAH, S.A.; MOTTRAM, T.T.; LINES, J.A.; WATHES, C.M. A review of livestock and monitoring and the need for integrated systems. Computers and Electronics in Agriculture, v.17, p.139-159, 1997.

GREINER, S.P. The use of ultrasound measurements in beef breeding programs. http://www.herfturf.com/ultrasound.htm, (15/Nov/2001).

HAMMOND, J. Farm animals. London:Edward Arnold, 1971. 322p.

HASSEN, A.; WILSON, D.E.; ROUSE, G.H. Evaluation of carcass, live, and real-time ultrasound measures in feedlot cattle: I. Assessment of sex and breed effects. Journal of Animal Science, v.77, p.273-282, 1999a. 
HASSEN, A.; WILSON, D. E.; ROUSE, G. H. Evaluation of carcass, live, and real-time ultrasound measures in feedlot cattle: II. Effects of different age end points on the accuracy of predicting the percentage of retail product, retail product weight, and hot carcass weight. Journal of Animal Science, v.77, p.283-290, 1999b.

HASSEN, A.; WILSON, D.E.; WILLHAM, R.L.; ROUSE, G.H. TRENKLE, A.H. Evaluation of ultrasound measurements of fat thickness and longissimus muscle area in feedlot cattle: Assessment of accuracy and repeatability. Canadian Journal of Animal Science, v.78, p.277285, 1998.

HERRING, W.O.; MILLER, D.C.; BERTRAND, J.K.; BENYSHEK, L.L. Evaluation of machine, technician, and interpreter effects on ultrasonic measures of backfat and longissimus muscle area in beef cattle. Journal of Animal Science, v.72, p.2216-2226, 1994.

HOUGHTON, P.L.; TURLINGTON, L.M. Application of ultrasound for feeding and finishing animals: A review. Journal of Animal Science, v.70, p.930- 941, 1992.

LUCHIARI FILHO, A. Pecuária da carne bovina. São Paulo: LinBife, 2000. 134p

MAY, S.G.; MIES, W.L.; EDWARDS, J.W.; HARRIS, J.J.; MORGAN, J.B.; GARRET, R.P.; WILLIANS, F.L.; WISE, J.W.; CROSS, H.R.; SAVELL, J.W. Using live estimates and ultrasound measurements to predict carcass cutability. Journal of Animal Science, v.78, p.1255-1261, 2000.

MOSER, D.W.; BERTRAND, J.K.; MISZTAL, I.; KRIESE, L.A.; BENYSHEK, L.L. Genetic parameters for carcass and yearling ultrasound measurements in Brangus cattle. Journal of Animal Science, v.76, p.2542-2548, 1998.

NATIONAL RESEARCH COUNCIL. Nutrient requirements of beef cattle. 7. ed. Washington: Academy Press, 1996. 242p.

OLTJEN, J.W.; SMITH, M.T.; DOLEZAL, H.G.; GILL, D.R.; BEHRENS, B.D. Evaluation of ultrasonic carcass fat thickness and muscle area prediction in feedlot steers. Journal of Animal Science, v.67, p.440, 1989.

PERKINS, T.L.; GREEN, R.D.; HAMLIN, K.E. Evaluation of ultrasonic estimates of carcass fat thickness and longissimus muscle area in beef cattle. Journal of Animal Science, v.70, p.1002-1010, 1992a.

PERKINS, T.L.; GREEN, R.D.; HAMLIN, K.E.; SHEPARD, H.H.; MILLER, M.F. Ultrasonic prediction of carcass merit in beef cattle: evaluation of technicians effects on ultrasonic estimates of carcass fat thickness and longissimus muscle area. Journal of Animal Science, v.70, p.2758-2765, 1992 b.
PERRY, T.C.; FOX, D.G. Predicting carcass composition and individual feed requirement in live cattle widely varying in body size. Journal of Animal Science, v.75, p.300-307, 1997.

PRADO, C.S.; PÁDUA, J.T.; SAINZ, R.D.; MAGNABOSCO, C.U.; COORRÊA, M.P.; RESENDE, L.S. Comparação de diferentes métodos de avaliação da área de olho-de-lombo e cobertura de gordura em quatro grupos genéticos de bovinos de corte castrados e inteiros suplementados a pasto. In: CONGRESSO BRASILEIRO DE CIÊNCIA E TECNOLOGIA DE CARNES, 1., São Pedro, 2001. Anais. Campinas: ITAL, 2001. p.367-368.

RENAND, G.; FISHER, A.V. Comparison of methods for estimating carcass fat content of young Charolais bulls in performance testing station. Livestock Production Science, v.51, p.205-213, 1997.

ROBINSON, D.L.; McDONALD, C.A.; HAMMOND, K.; TURNER, J.W. Live animal measurements of carcass traits by ultrasound: assessment and accuracy of sonographers. Journal of Animal Science, v.70, p.1667$1676,1992$.

SAS INSTITUTE. SAS/STATTM guide for personal computers. 6.ed. Cary, 1987. 1028p.

SILVA, S.L.; LEME, P.R.; FIGUEIREDO, L.G.G.; PEREIRA, A.S.C.; PUTRINO, S.M. Correlações entre características de carcaça obtidas in vivo por ultra-sonografia e na carcaça post mortem em novilhos Nellore. In: REUNIÃO DA SOCIEDADE BRASILEIRA DE ZOOTECNIA, 38 ., Piracicaba, 2001. Anais. Piracicaba: SBZ, 2001. p.1206-1208.

SILVEIRA, A.C.; ARRIGONI, M.D.B.; CHARDULO, L.A.L.; SILVEIRA L.G.G.; COSTA, C.; OLIVEIRA, H.N. Sistema de produção de novilhos superprecoces. In: SIMPÓSIO GOIANO SOBRE PRODUÇÃO DE BOVINOS DE CORTE, 1., Goiânia. Anais. Goiânia: CBNA, 1999. p.105-122.

SMITH, M.T.; OLTJEN, J.W.; DOLEZAL, H.G.; GILL, D.R.; BEHRENS, B.D. Evaluation of ultrasound for prediction of carcass fat thickness and longissimus dorsi area in feedlot steers. Journal of Animal Science, v.70, p.29-37, 1992.

WALDNER, D.N.; DIKEMAN, M.E.; SCHALLES, R.R.; OLSON, W.G.; HOUGHTON, P.L.; UNRUH, J.A.; CORAH, L.R. Validation of realtime ultrasound technology for predicting fat thickness, longissimus muscle areas, and composition of Brangus bulls from 4 months to 2 years of age. Journal of Animal Science, v.70, p.3044-3054, 1992.

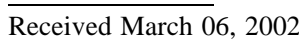

Accepted June 10, 2003 